\title{
Music for Prague 1968: A Display of Czech Nationalism from America
}

\author{
Zachary CAIRNS \\ University of Missouri - St. Louis \\ 243 Pond Hollow Drive, MO 63303 St. Charles, USA \\ E-mail: cairnsz@umsl.edu
}

(Received: April 2015; accepted: June 2015)

\begin{abstract}
As an overt response to the Soviet bloc invasion of Czechoslovakia, Karel Husa's Music for Prague 1968 makes an obvious nationalistic statement. In his foreword to the published score, Husa describes Prague's use of the Hussite war song "Ktož jsú boží bojovníc" as its most important unifying motive. He says this song has long been "a symbol of resistance and hope." The author does not debate the work's nationalistic intent, he finds remarkable that, in 1968, Husa was an American citizen, teaching at Cornell, and using compositional techniques not frequently associated with Eastern European nationalism. If musical nationalism (expressed by folkloric elements) in Eastern European countries can be used to express primacy over avantgarde music, Music for Prague 1968 presents the opposite - a traditional war song submersed in an entirely Western European/American musical language. The study examines several portions of the composition to demonstrate the ways in which Husa expresses his nationalism in a non-nationalistic manner, including chromatic transformations of the Hussite song; the integrally serial third movement, in which unpitched percussion instruments are intended to represent the church bells of Prague; and the opening movement's non-tonal bird calls, intended to represent freedom. Furthermore, Music for Prague 1968 uses a Western avant-garde language in a way that Husa's other overtly nationalistic post-emigration pieces (Twelve Moravian Songs, Eight Czech Duets, Evocations of Slovakia) do not. In this light, it will be seen that Music for Prague 1968 fills a special role in Husa's nationalistic display.
\end{abstract}

Keywords: Karel Husa, Music for Prague 1968, concert band, serialism, nationalism, sketch studies, Hussite, Czechoslovakia, Soviet Union

Karel Husa's Music for Prague 1968 is widely recognized as one of the most significant works composed for concert band. Following its premiere, the piece 
became an immediate staple of the repertoire. As of 1991, the last date where any somewhat official count appears to have been attempted, the work had been performed over 7,000 times. ${ }^{1}$ Though he has an extensive catalog, Music for Prague 1968 is unquestionably one of Husa's best-known compositions. ${ }^{2}$

As an overt response to the Soviet bloc invasion of Czechoslovakia, Husa's Music for Prague 1968 (henceforth, MfP) makes a strong nationalistic statement, even understood by some to be a "personal gesture of outright defiance." ${ }^{3}$ In his foreword to the published score, Husa describes MfP's use of the $15^{\text {th }}$ century Hussite war song "Ktož jsú boží bojovníc" [Ye warriors of god] as its most important unifying motive. He says this song has long been "a symbol of resistance and hope" (Plate 1). ${ }^{4}$

While I do not debate the work's nationalistic intent, it is important to remember that in 1968 Husa was an American citizen. He was a faculty member at Cornell University, and was writing music using compositional techniques not frequently associated with Eastern European nationalism. If musical nationalism (expressed by folkloric elements such as the Hussite song that permeates the score of $M f P$ ) in Eastern European countries can be used to express primacy over avant-garde music, MfP presents us with the opposite - a traditional war song submersed in an entirely Western European/American musical language.

This paper will examine several portions of $M f P$ to demonstrate the ways in which Husa expresses his support for the Czech people in a manner not traditionally associated with Czech music, including chromatic transformations of the war song; the integral serialism of the third movement, in which unpitched percussion instruments are used to represent the church bells of Prague; and the opening movement's atonal bird calls, intended to represent freedom. Furthermore, I will demonstrate how MfP uses a Western avant-garde language in a way that Husa's other overtly nationalistic post-emigration pieces do not. In this light, it will be seen that Music for Prague 1968 fills a special role in Husa's nationalistic display.

The story behind the conception and composition of MfP is not at all unknown, but bears a brief repetition here. On the evening of 21 August 1968, Husa, who had been born in Prague but was living in Ithaca, New York, heard the news of the in-

1. Susan Hayes Hitchens, Karel Husa: A Bio-Bibliography (New York: Greenwood Press, 1991), 10. Most of these performances were of Music for Prague 1968 in its original format, but approximately 400 performances were of Husa's own orchestral transcription of the work. The work was not performed in Czechoslovakia until 1990, when the composer was invited to Prague to lead a performance of the Bohuslav Martinů Philharmonic. See Wanda Dobravka, "Karel Husa in Prague," Music News from Prague (November 1990), 1.

2. While it appears frequently on concert programs to this day, Music for Prague 1968 has received relatively scant attention in music theoretical and musicological publications. Most of the publications dealing with this work are intended for wind ensemble performers and conductors to aid in the preparation of the work for performance. A notable exception is Lawrence Hartzell, "Karel Husa: The Man and His Music," The Musical Quarterly 62/1 (January 1976), 87-104.

3. Christopher Neal, "Karel Husa's Music for Prague 1968: An Exploration of Compositional Process and Historical Background," DMA document, University of Oklahoma (2002), 32.

4. Karel Husa, "Foreword," in Music for Prague 1968 (New York: Associated Music Publishers, 1969). 
vasion of Czechoslovakia by the Soviet-led Warsaw Pact armies. He stayed up for much of the night, listening to the radio for any reports he could find. So disturbed by the news, Husa decided to use a recently accepted commission from Kenneth Snapp and the Ithaca College Concert Band as a means to express his feelings through a new composition. Over the course of six or seven weeks, he completed the four-movement, 22-minute work, and the Ithaca College Band premiered it at the Music Educators' National Conference in Washington, DC in January, 1969. ${ }^{5}$

MfP uses a wide variety of musical gestures to recall and represent images of Prague. Shown in Plate 1, the score's Foreword, which Husa requests be printed or read aloud at all performances of the work, points specifically to the sounds of unpitched, metallic percussion instruments as representing the sound of church bells ringing throughout the City of a Hundred Spires; to the opening piccolo solo, meant to sound like a bird call used to represent freedom; and, most obviously, to

Plate 1 Karel Husa, Music for Prague 1968, Foreword

\section{FORE WOR D*}

Three main ideas bind the composition together. The first and most important is an old Hussite war song from the 15th century, "Ye Warriors of God and His Law," a symbol of resistance and hope for hundreds of years, whenever fate lay heavy on the Czech nation. It has been utilized also by many Czech composers, including Smetana in My Country. The beginning of this religious song is anounced very softly in the first movement by the timpani and concludes in a strong unison (Chorale). The song is never used in its entirety.

The second idea is the sound of bells throughout; Prague, named also the City of "Hundreds of Towers," has used its magnificently sounding church bells as calls of distress as well as of victory.

The last idea is a motif of three chords first appearing very softly under the piccolo solo at the beginning of the piece, in flutes, clarinets and horns. Later it reappears at extremely strong dynamic levels, for example, in the middle of the Aria.

Different techniques of composing as well as orchestrating have been used in Music for Prague 1968 and some new sounds explored, such as the percussion section in the Interlude, the ending of the work, etc. Much symbolism also appears: in addition to the distress calls in the first movement (Fanfares), the unbroken hope of the Hussite song, sound of bells, or the tragedy (Aria), there is also the bird call at the beginning (piccolo solo), symbol of the liberty which the City of Prague has seen only for moments during its thousand years of existence.

K.H.

*It is the composer's wish that his Foreword be printed in its entirety in all concert programs or read to the audience before each performance of the work.

5. Karel Husa, "Music for Prague 1968," in The College and University Band: An Anthology of Papers from the Conferences of the College Band Directors National Association, 1941-1975, compiled by David Whitwell and Acton Ostling (Reston, VA: Music Educators National Conference, 1977). 
the use of the first 4 measures from a Hussite war song (see Example 1) as a unifying motive throughout, not unlike Smetana's use of the same song throughout the "Tábor" movement of his Ma Vlast. ${ }^{6}$

EXAMPLE 1 Hussite War Song “Ktož jsú boží bojovníc” [Ye warriors of god]

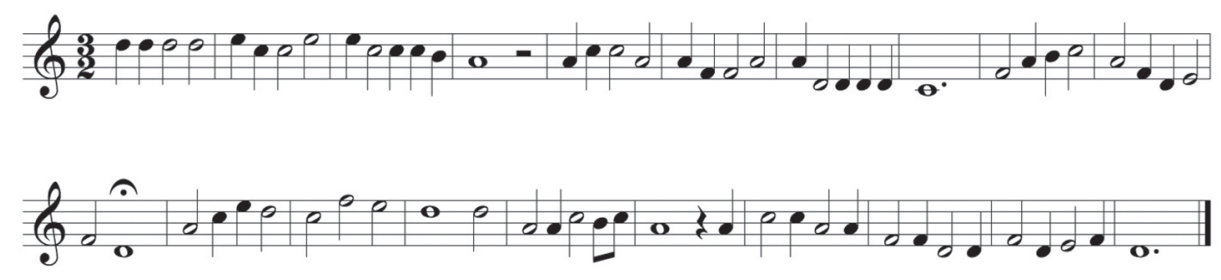

Husa also employs two distinct twelve-tone rows as generators of pitch material (Example 2). Additionally, militaristic sounds of snare drums and fanfare trumpets populate the score, and the sounds of battle are frequent throughout the piece, particularly during the first and last movements.

Example 2 Two Primary Rows from Music for Prague 1968
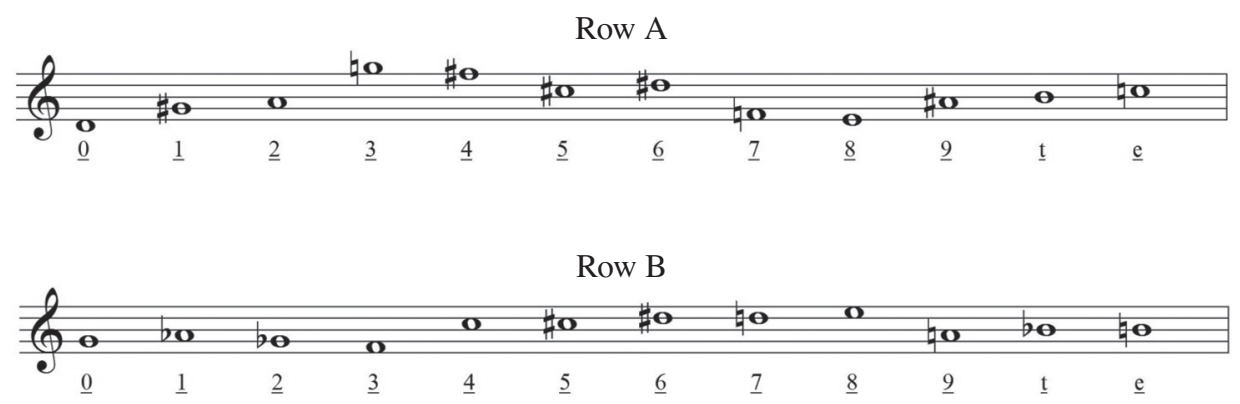

While Music for Prague uses these specific representational musical ideas, it is important to remember that, at this point in his life, Husa was creating his display of the resilience and strength of the Czech nation while being himself a citizen of the United States of America. He left Czechoslovakia and lived in Paris where he studied with Arthur Honegger and Nadia Boulanger from 1946 to 1954. During this time, he forfeited his Czechoslovakian citizenship and moved to the United States to accept a position in 1954 at Cornell University in Ithaca, New York.

6. Smetana was not the only earlier Czech composer to draw from this war song. Byron Adams points out that this war song is also present in Dvoŕák's overture's My Home (op. 62) and Hussite Overture (op. 67) and Josef Suk's symphonic poem Prague. See Byron Adams, "Karel Husa's Music for Prague 1968: An Interpretive Analysis," The Instrumentalist 42/3 (October 1987), 20. 
Husa's compositional language was largely tonal and neo-classical when he lived and studied in Prague and Paris; in the late 1950s, while living in America, he began writing atonal and serial works.

Music for Prague was composed at a point in Husa's life where, though his feelings toward his native Prague were still strong, his compositional language had become wholly American. ${ }^{7}$ As a result, there exists an interesting dichotomy between the nationalistic intent of the work and the modernist approach used to project that intent. Some of this contrast is used to achieve a programmatic effect, such as the moment shown in Example 3. In this excerpt, the woodwinds and

Example 3 Printed score of Music for Prague 1968, first movement, rehearsal mark $\mathrm{G}^{-4}-\mathrm{G}^{-2}$

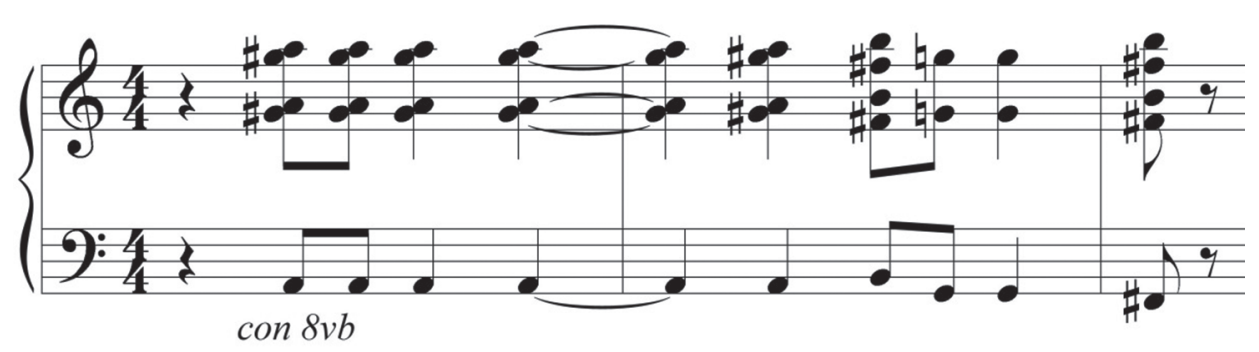

horns pass around a winding chromatic figure, ${ }^{8}$ layered in such a way to produce a wild, chaotic effect, which is briefly overpowered by the war song (cf. the brass section in first system of the reduction in Example 4).

The temptation to extrapolate from this programmatic moment is great. Indeed, some authors have attempted to read the Hussite theme and the freely atonal and dodecaphonic music as recurring characters in an ongoing depiction of the 1968 invasion. ${ }^{9}$ In this interpretation, the atonal and dodecaphonic music are seen to represent the "oppressive" march of the Soviet army, and the war song represents the resistance of the Czech people. While this kind of narrative may be helpful in evoking a particular approach to performance, or in expressing the ideas of

7. A thorough discussion of the nature of Socialist Realist music in Czechoslovakia during this time is beyond the scope of the present paper. Readers interested in more detail about this topic should consult Miloš Jůzl, "Music and the Totalitarian Regime in Czechoslovakia," International Review of the Aesthetics and Sociology of Music, 27/1 (June 1996), 31-51; and Mikuláš Bek, "Socialist Realism and the Tradition of Czech National Music Or Who Goes with Whom?" In Musicologica Olomucensia VI, Acta Universitatis Palackianae Olomucensis (Olomouc: Univerzita Palackého v Olomouci, 2001) 39-50.

8. This figure is first introduced at the beginning of the first movement's Allegro section, where the trumpets enter with a fanfare based on Row B.

9. See, in particular, Byron Adams, "Karel Husa's Music for Prague 1968" and Chris Sharp, "A Study of Orchestration Techniques for the Wind Ensemble/Wind Band as Demonstrated in Seminal Works" (Ph.D. diss., University of Florida, 2011). 
EXAMPLE 4 Brass statement of "Ye Warriors of God" and the following measures, Music for Prague 1968, first movement, $\mathrm{G}^{-2}-\mathrm{G}^{+4}$, reduction
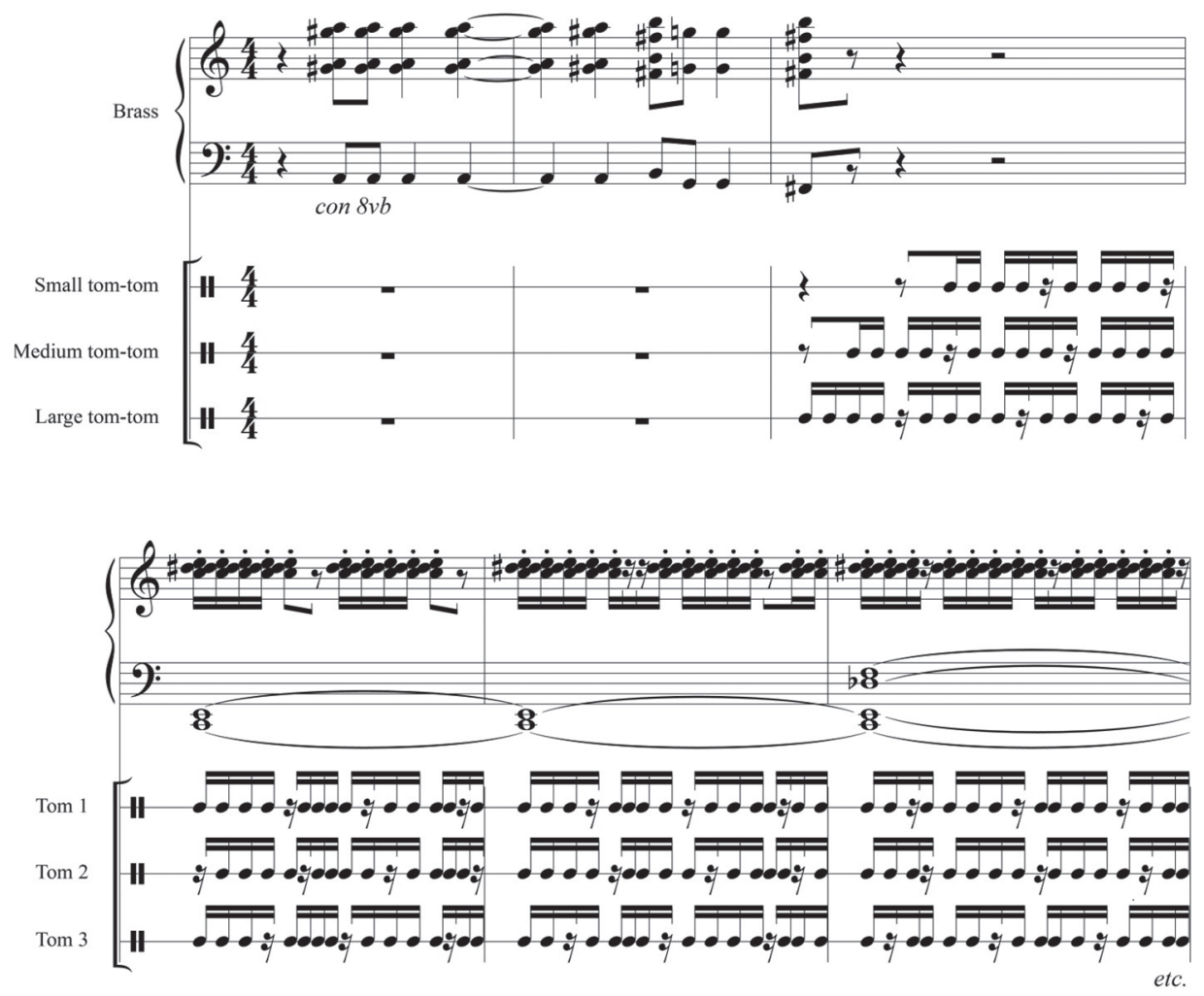

the piece in a program note aimed at a general audience, it is far from convincing on much more than a superficial level.

For example, in the excerpt shown in Example 3, the trumpets and low brass play the war song. But the theme itself is presented in an extremely dissonant harmonization, with a biting half-step crunch. Immediately following this purported outburst of resistance, the trumpets (who, earlier in the movement, used twelvetone fanfares to announce the arrival of the Soviet army $)^{10}$ immediately abandon the Hussite theme to join the cause of the invading army, partnering with the military drums in their syncopated rhythmic patterns (Example 4). As is easily seen, the mapping of "atonal/dodecaphonic music = invading army" and "Hussite war song $=$ Czech resistance" cannot be applied with any degree of generality.

Rather than attempting to label certain musical elements as "Czech" and others as "Soviet," it is more important to take note of the ways in which Husa has 
submersed these apparently nationalistic or symbolic Czech elements in an entirely Western European/American musical language. Example 5 shows the opening phrase of $M f P$.

EXAMPLE 5 First movement, measures 1-4, reduction
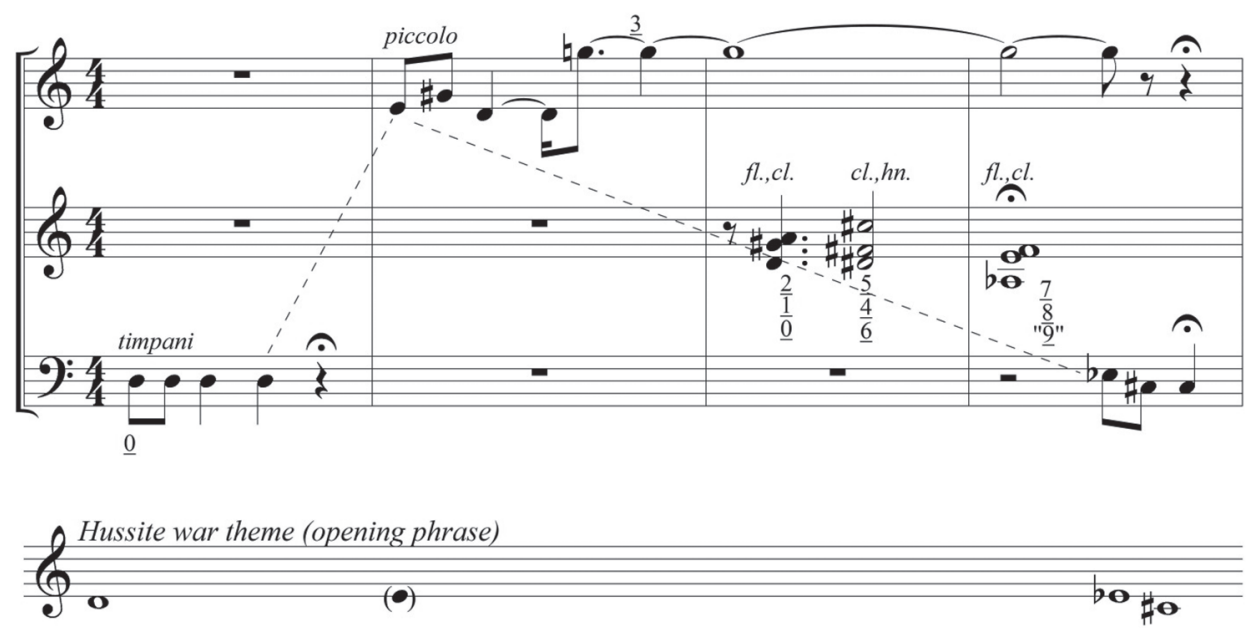

The first sound in the piece is that of muted timpani, intoning the opening rhythm of the war song. A solo piccolo interrupts, playing what Husa describes as a bird call, which he sees as a symbol of freedom. Three soft, dissonant chords support this solo, and the four-measure phrase concludes with the timpani playing the next three notes of the Hussite theme. The timpani's version of the war song is chromaticized: where the notes should be $\mathrm{D}-\mathrm{E}-\mathrm{C}$, Husa instead surrounds the opening pitch with semitones, as $\mathrm{D}-\mathrm{E},-\mathrm{C} \sharp{ }^{11}$ The accompanying chords on the middle staff are taken from three-note segments of one of Row A (cf. Example 2). ${ }^{12}$ The piccolo solo in measure 2 is taken from this row as well. The E$\mathrm{G} \sharp-\mathrm{D}$ figure contains the row's first two notes, followed by a high $\mathrm{G}$, the note found at order position $\underline{3} \cdot{ }^{13}$ But the E that begins the piccolo solo is far out-ofplace: it should be at order position 9 in the row, and here it is found at the very beginning of the phrase. This note serves as a connecting pitch between the timpani's opening $\mathrm{D}$, and its eventual resumption on $\mathrm{E}$, and $\mathrm{C} \sharp$. The $\mathrm{E}$ q in the piccolo

11. Hartzell makes a similar point about the passing of the war song from timpani to piccolo and back, but layers a tonal reading (of the C $¥$ as a leading tone) with which I disagree. See Hartzell, "Karel Husa," 94.

12. The A, here is listed as order position "9," even though order position 9 should actually be A\#, as found in the primary row. An early sketch by Husa (shown here as Example 10), has this chord written with an A\# in place of the "incorrect" A, found in the published score. To be clear, I do not believe this to be a publisher's misprint, but I am uncertain of when and why Husa made the decision to change the sketched $\mathrm{A} \#$ to $\mathrm{A}$.

13. Following the convention established by Andrew Mead, I will underline order position numbers to visually distinguish them from pitch-class integers. See Andrew Mead, "Large-Scale Strategy in Arnold Schoenberg's Twelve-Tone Music," Perspectives of New Music 24/1 (Autumn-Winter 1985), 120-157. 
is the "correct" (which is to say, non-chromaticized) second pitch of the war song. So, in the opening four measures, we are presented with a disjunct version of the $15^{\text {th }}$-century war song consumed from the inside by a twelve-tone row.

At least one author has noted what he considers a "progression" in the nature of the serial approach used through MfP's four movements. ${ }^{14}$ The first movement uses both Rows A and B in a rather fragmentary nature like that described in the preceding paragraph - it is rare to see a full statement of all twelve pitch classes in their predetermined order. The second movement, though, is based almost entirely on transformations of Row B. Order position manipulations are present, but it is fairly easy to trace the row forms being used - it is perhaps the closest to Viennese "classical" dodecaphony. The third movement, written for percussion quintet alone, extends the control of the serial approach to non-pitch musical domains: duration, dynamics, and timbre. Finally, the fourth movement relies only on twelvetone techniques in the moments where it recalls events from the first movement. A tempting narrative arises from this apparent progression: serialism represents oppression, and that oppression gradually takes over the compositional process through the first three movements, until, after reaching its most controlling point in the third movement, the musical material breaks through from the restraints of the dodecaphonic system, and the Hussite war theme reigns supreme, showing the strength and resilience of the Czech nation. Tempting, indeed, but utterly flawed.

An examination of the flaws of this narrative shows us another way in which Husa's treatment of his musical material is too complex to be characterized by a single metaphor such as this. In the third movement, the beginning of which is shown in Example 6, we find another occurrence of nationalistic symbolism mixed with modernist sensibilities. This movement, titled "Interlude," finds three of the five percussionists playing twelve different metallic instruments: antique cymbals, triangles, suspended cymbals, and tam-tams of small, medium, and large sizes. The metallic texture is enhanced by the use of a solo vibraphone, and a muffled snare drum with snares turned off provides a rhythmic and textual contrast.

The vibraphone and snare drum share a sort of dialogue throughout the movement's arch form. With the exception of the very beginning and ending of the movement, the snare drum plays very short rudimental bursts of notes, answered by the vibraphone's long notes with gently rising and falling dynamics. All of this occurs over a non-metric tapestry of metallic sounds. In the narrative that I previously described as "tempting," Christopher Neal makes the claim that the integral serialism applied for the metallic parts is the strictest of the serial methods used in the piece and, therefore, represents the pinnacle of the invading army's control over Czechoslovakia. ${ }^{15}$ But one problem here lies in Husa's use of these techniques

14. Neal, "Karel Husa's Music for Prague 1968."

15. Neal, "Karel Husa's Music for Prague 1968," 86-87, 117-118. 
Example 6 Printed score of Music for Prague 1968, beginning of the third movement

III. Interlude

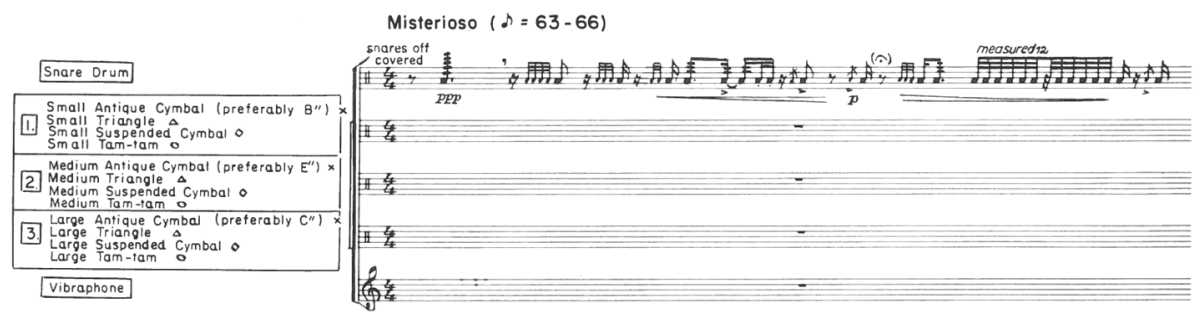

$=$

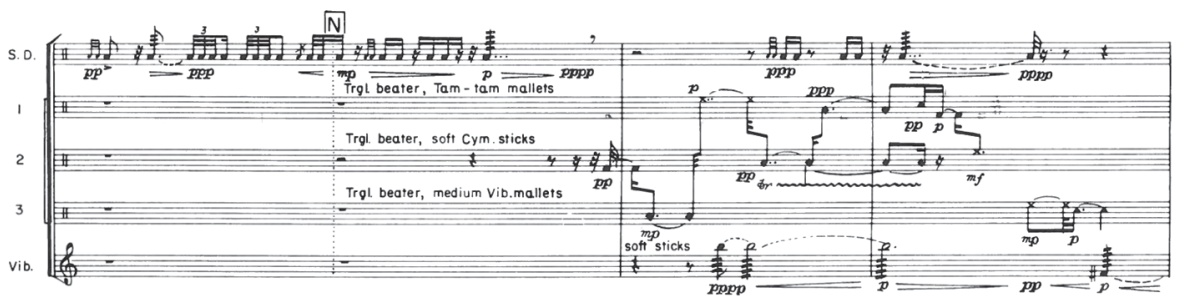

$=$

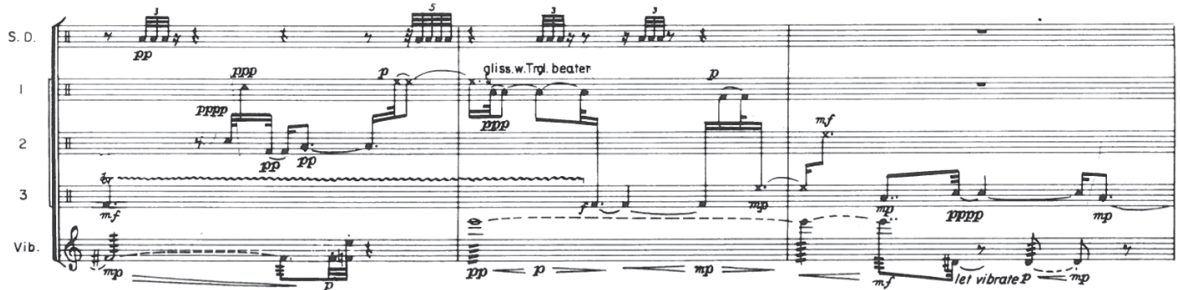

- they are used exclusively with the parts of the music that represent the city of Prague itself. I believe that the strict integral serialism used here arose from more pragmatic concerns. Specifically, church bells chime at predetermined, regular intervals, which can be easily expressed through strict control of note durations; the positioning of the bells around the city can be easily expressed through a similarly strict control of dynamics. ${ }^{16}$ If the metallic percussion instruments are supposed to sound like a large number of church bells ringing, then it is not difficult to see how an American composer in the late 1960s might find integral serialism as a perfect way to create a realistic depiction of that sound.

16. Husa's own performance note for this movement suggests that the composer was thinking spatially to some degree. He requests that the metallic instruments be spread across the entire rear of the percussion ensemble, rather than being in close proximity to one another. 
EXAMPLE 7 Sketch to the third movement ${ }^{17}$

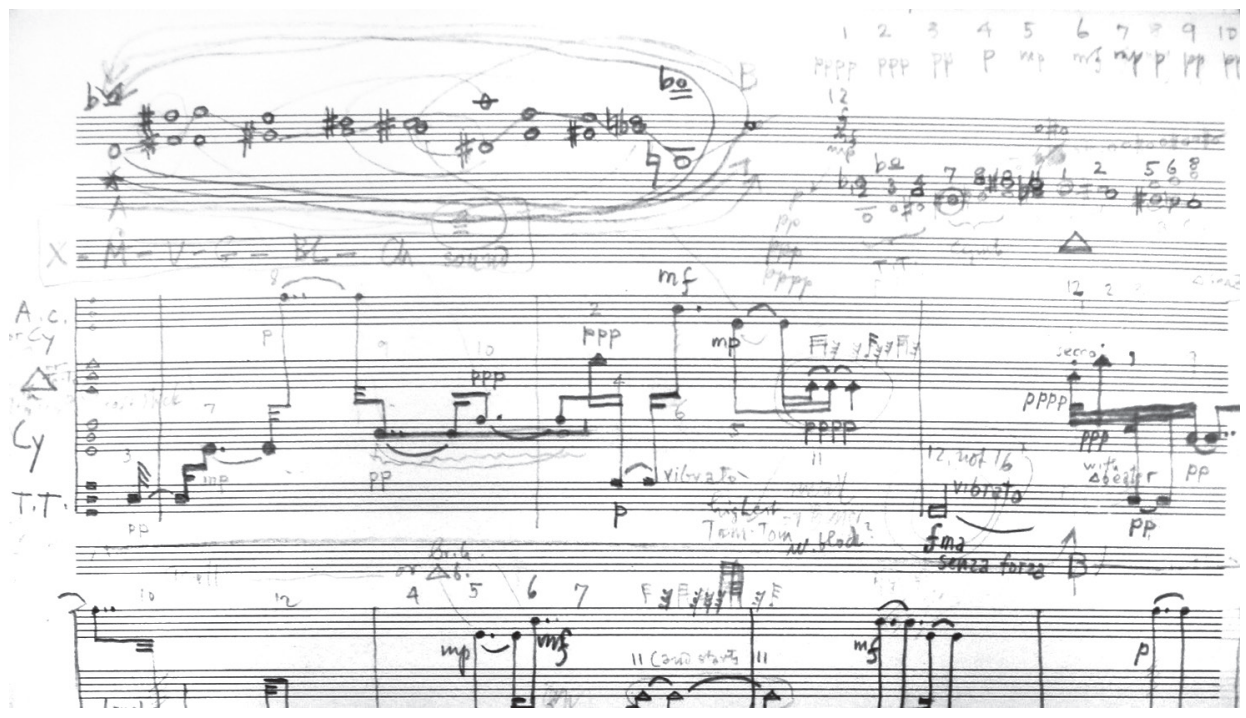

Of course, even more telling is that, by this point in his career, serial and other types of atonal writing were simply basic parts of Husa's style - it was not merely a gimmick he employed for programmatic effect. In the time after his departure from Czechoslovakia, Husa did not compose large numbers of pieces with direct references to Czech music. In fact, his catalog lists only three pieces from 1945 through 1968 that are ostensibly nationalistic: the 1951 Evocations of Slovakia, composed when he was living in Paris, and the 1955 Eight Czech Duets and the 1956 Twelve Moravian Songs, both composed when he was living in New York.

The two American pieces both appear to have been written for young musicians - the technical demands are not great, the harmonic language is not wildly dissonant, and the individual movements within each set are relatively short. Evocations of Slovakia is somewhat different, being a virtuosic chamber piece for clarinet, viola, and cello. Its overall language is tonal, but of varying degrees of looseness throughout. Music for Prague, then, occupies a unique place in Husa's early nationalistic output. Here we see Husa, for the first time, combining Czech nationalistic elements with dodecaphonic techniques. If the combination was not done for the purpose of painting a picture of the invasion with contrasting compositional approaches, why use dodecaphony as a way of showing nationalist pride here?

There are certainly a number of possible answers here, but I would like to provide one that has not gotten any attention in the published literature. My time

17. Used by perission of the Karel Husa Archive and Gallery for Contemporary Music, Ithaca College School of Music. 
EXAMPLE 8 Dark-ink sketch to the secondary row for "Aria"

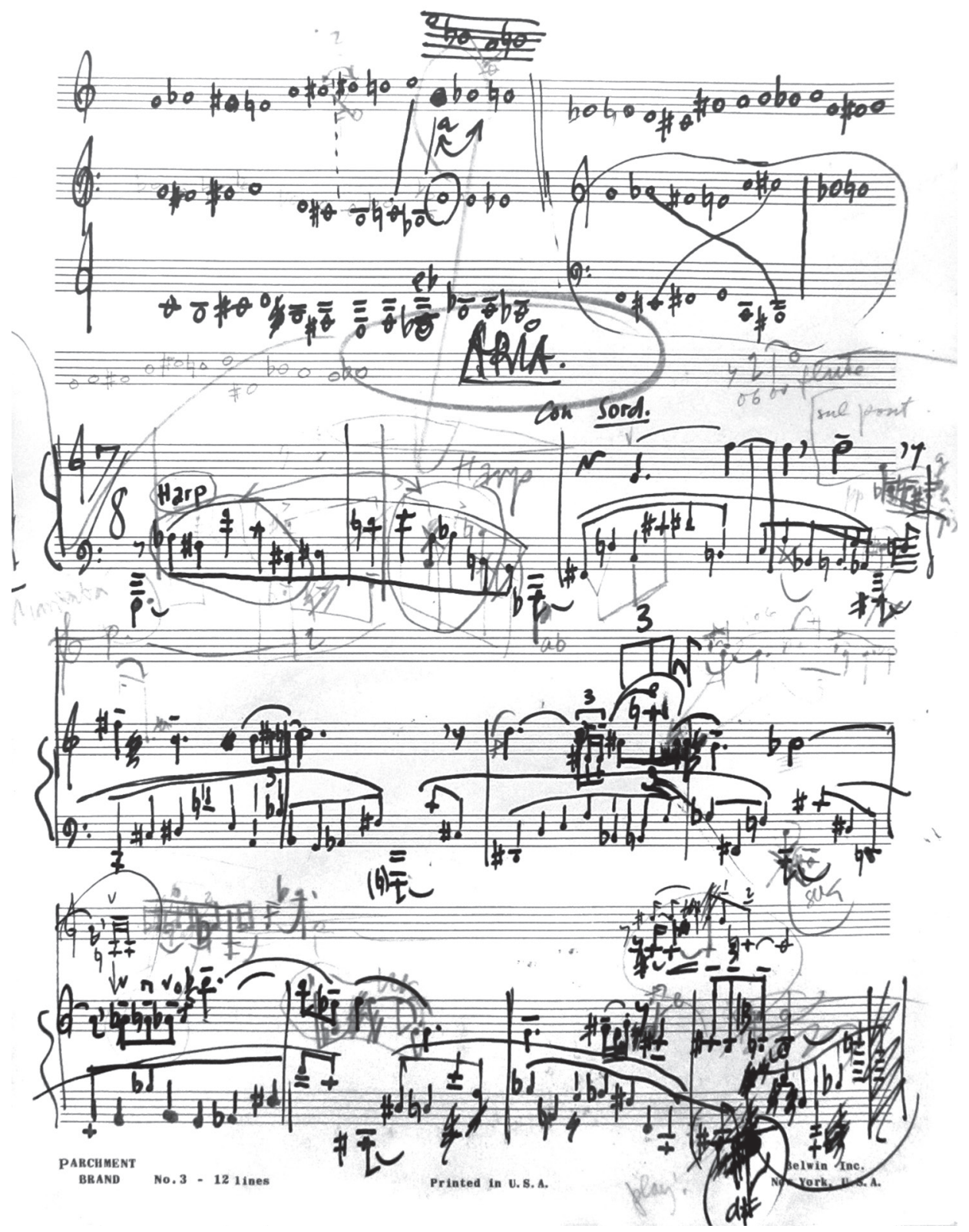


EXAMPLE 9 Second movement, measures 1-9, reduction

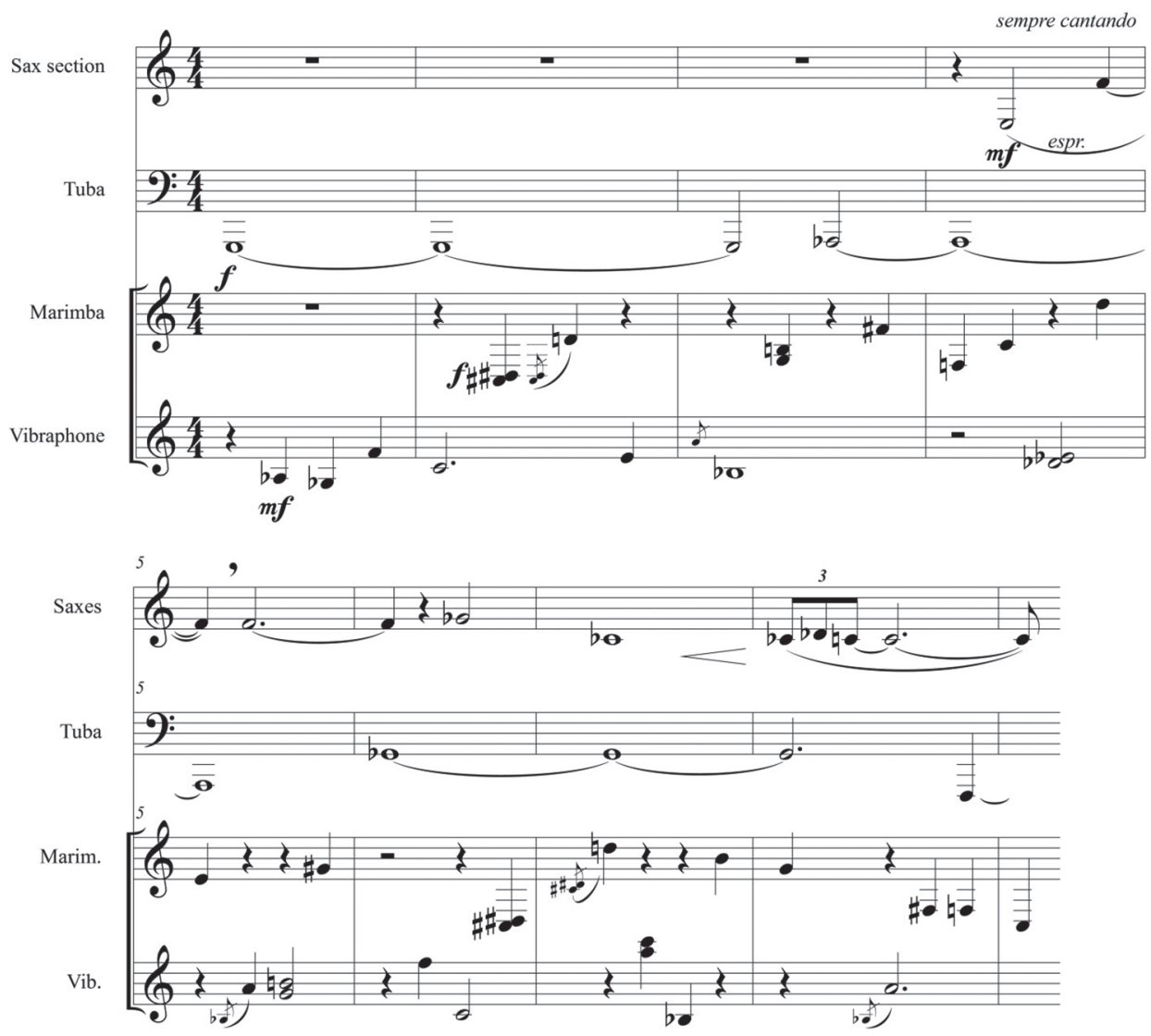

looking at the sketches for this piece in the Husa Archive at Ithaca College suggests to me that a good bit of the compositional material used in MfP appears to have been planned prior to the Warsaw Pact army invasion. It is no secret that Husa had already accepted the Ithaca College commission before August 21, and while I do not believe that these sketches were for that particular purpose at that time, it is fairly clear that Husa was in the beginning stages of composing a piece that used a great deal of the same material, minus the Hussite war theme and minus the integrally serial percussion movement.

Most of the sketches in the Music for Prague folders in the Husa Archive that are immediately recognizable as specific moments of $M f P$ are written in pencil, and occasionally using various colored pencils.

The sketch shown in Example 7 shows the pitch-class derivation of the timbre and dynamic rows for the third movement. This sketch is a representative example 
of many of the other sketches for $M f P$, though the heavy pencil strokes suggest that this is a fairly late sketch, mostly well thought-out.

The sketch shown in Example 8, on the other hand, is the first of eleven pages of sketches of a very different appearance. Here we see heavy ink writing, on a different size and brand of manuscript paper. The word "Aria" is the title of the second movement of $M f P$, and the row at the top of the page is the row that makes up the majority of the material of that movement. But the score for MfP's "Aria" is not in $7 / 8$, there is no harp playing the moving eighth notes, and the melodic instrument is not played "con sord." as this sketch indicates (cf. Example 9).

Compared with the first page of the score for the published "Aria," a reduction of which is shown in Example 9, it is easy to see similarities - an isochronous accompaniment pattern which uses (at least initially) the same progression of row forms as seen in the sketch, and a melody (in the tutti saxophone section) which uses the same row forms with the same melodic contour as seen in the sketch. Structurally, the sketch and the published version are identical, but the realization of that structure is very different.

Several pages of dark-ink sketches later, we find Husa working with the row that will eventually be used in the introduction of the first movement (Example 10). The prime form of that row is on top, and its sum-7 inversion is below it.

EXAMPLE 10 Dark-ink sketch of the first movement, measures 1-4

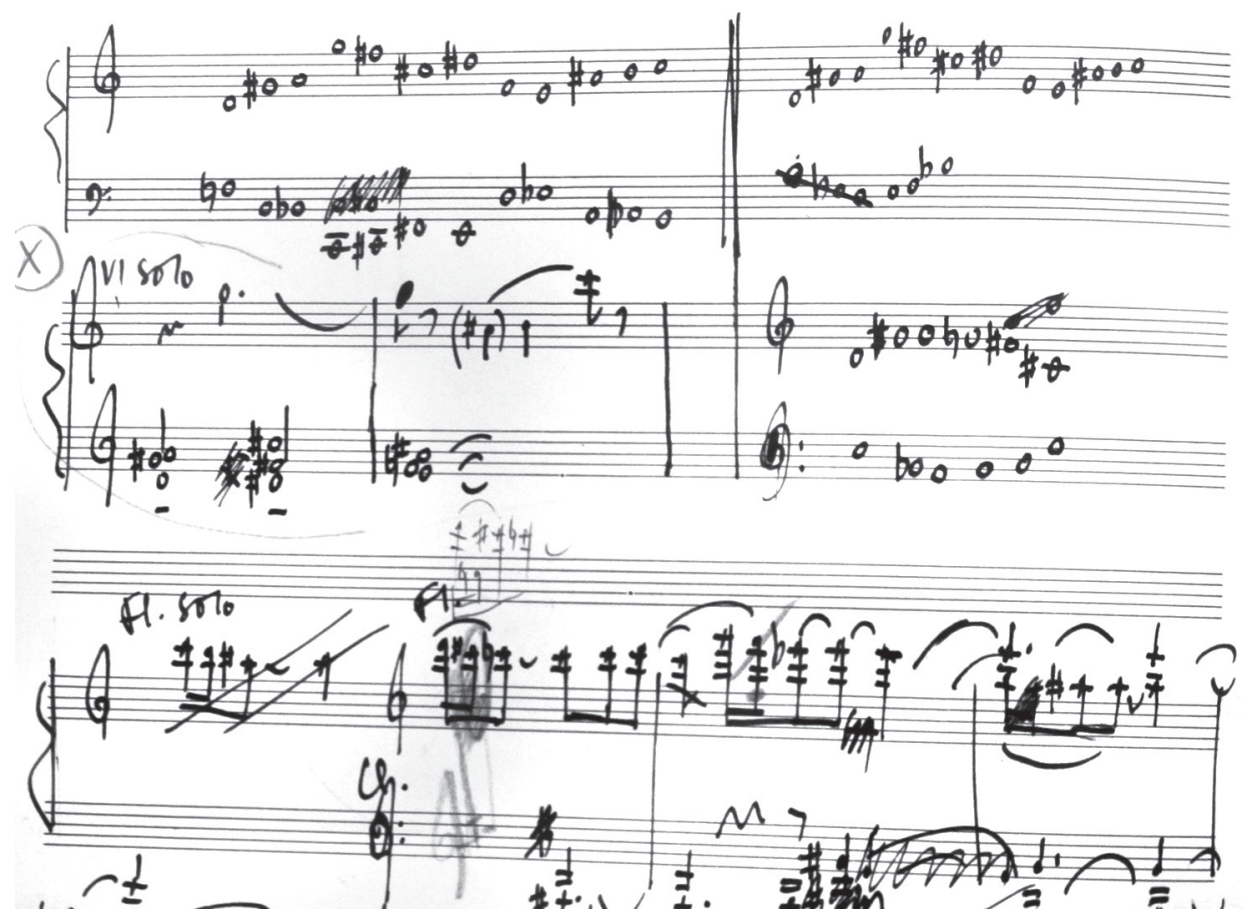


To the right, we see Husa experimenting with other transformations of the row's first hexachord. The fragment marked " $X$ " will eventually become measures 1-4 of the opening piccolo solo, but marked as a violin solo (Example 11).

EXAMPLE 11 Relationship between the sketch and the published version of measures 1-4 of the first movement

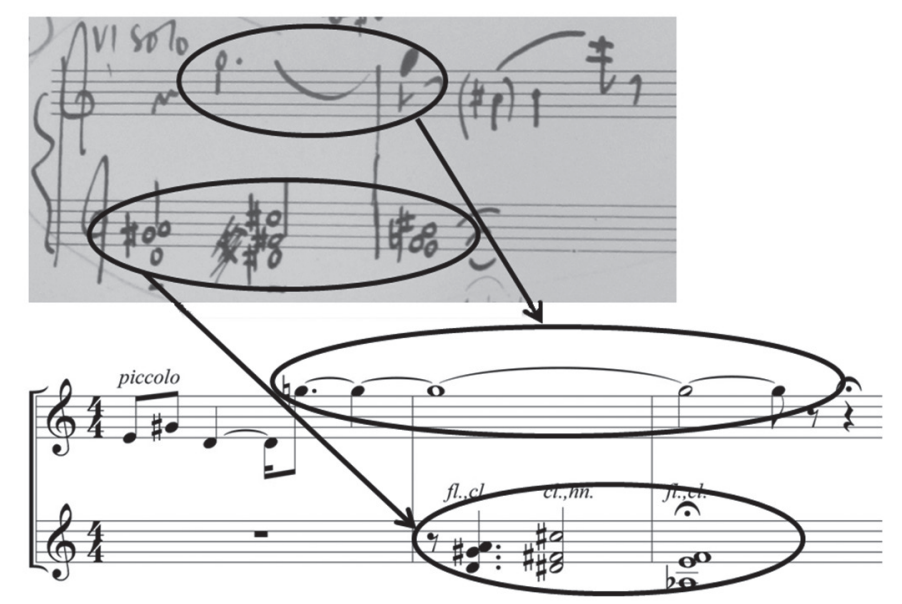

Example $12 a$ shows the top of the next sketch page. Here, we see something even closer to that piccolo solo, filled out a bit, still for violin, and this time without the chorale chords, but with harp and percussion providing an accompanimental texture.

Example $12 b$ shows an enlargement of the top left corner of this page. In this corner, we find a little clue, written in very light pencil. " 4 percussion, 5 winds, 2 harp, 2 piano-celesta, 1 violin." It appears that Husa may have been considering a piece, or at least part of a piece, for a small chamber wind ensemble with violin soloist. The remaining dark-ink sketches provide more connections with MfP, but none of them are any closer than these to the finished version.

At this point, I do not know for certain when Husa wrote these eleven pages of $M f P$-like music. But as they all appear to bear embryonic relationships to the published concert band piece, and because he does not have in his catalog a composition for the chamber wind ensemble he indicates, the most logical conclusion appears to be that he was working on these musical ideas prior to the August invasion of Czechoslovakia, and eventually re-purposed them, interweaving them with "Ye Warriors of God," making the opening violin solo into more of a birdcall, and using the percussion ensemble he had already designed in a manner to depict Prague's bells. Since Husa reports that the Ithaca Concert Band commission was asking for a piece to be completed, copied, and distributed to the per- 
EXAMPLE 12a Dark-ink sketch of first movement, measures 5-8

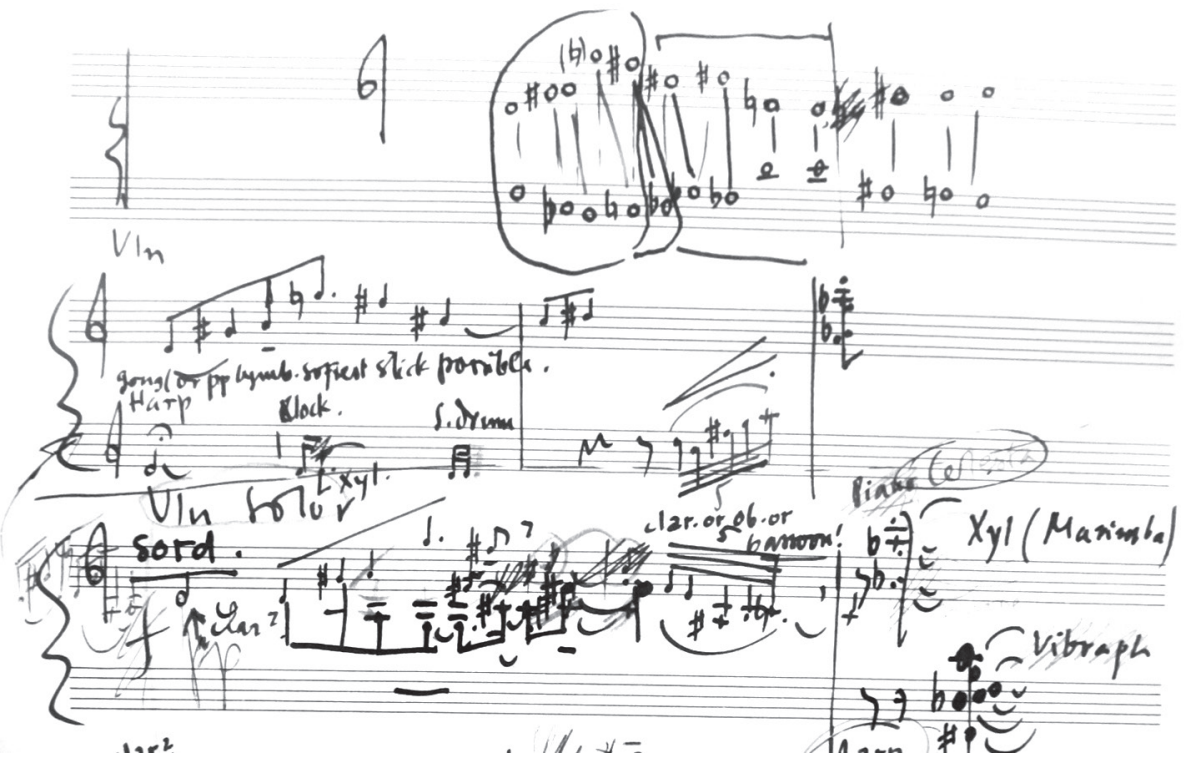

EXAMPLE 12b Close-up of the instrumentation list from the same sketch

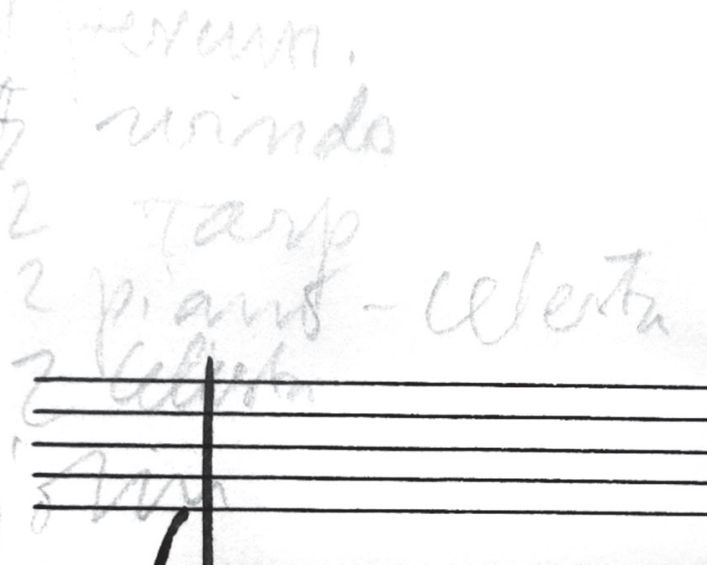

formers in just under two months, it seems reasonable to suspect that, when Husa's muse spoke to him in August using the voice of a Soviet tank, he may have found an unexpected way of tying together his current musical ideas with the commission he needed to fulfill. 
Its genesis notwithstanding, Music for Prague 1968 is clearly an important piece in Karel Husa's compositional output. It seems unfortunate that we have so long been satisfied with casual explanations of the work as being able to be reduced to a simple contrast between good and bad, Czech and Soviet, tonal and atonal. The relationships between the different kinds of musical material in MfP are much more nuanced and subtle than these reductive theories suggest. What we see in MfP is the merging of a number of compositional approaches in which some elements are given programmatic or at least representational significance. The purpose of the present paper has been to tease apart a few of these relationships, as well as to speculate on their origins, in the hopes that a less one-dimensional understanding of Music for Prague 1968 may begin to emerge. 